Journal of Bangladesh Academy of Sciences, Vol. 37, No. 1, 93-101, 2013

\title{
EVALUATION OF THE PERFORMANCE OF NATIVE CHICKEN AND ESTIMATION OF HERITABILITY FOR BODY WEIGHT
}

\author{
S. FARUQUE, M.S. ISLAM*, M. A. AFROZ ${ }^{1}$ AND M. M. RAHMAN \\ Poultry Production Research Division, Bangladesh Livestock Research Institute, Savar, \\ Dhaka, Bangladesh
}

\begin{abstract}
The study was conducted to compare the performance of chickens of non-descript desi (ND), hilly $(\mathrm{H})$ and naked neck (NN) genotypes. Data were analyzed by GLM procedure of SPSS in a CRD. The highest hatchability was found in third hatch of ND $(86.38 \%)$. The chick weight was influenced $(\mathrm{p}<0.05)$ by the egg weight. The average initial body weight of day-old chicks differed significantly $(\mathrm{p}<0.001)$ by genotypes. The lowest and highest mean body weight gain per bird were recorded for ND $(329.38 \pm 3.32 \mathrm{~g})$ and $\mathrm{NN}(351.56 \pm 5.08 \mathrm{~g})$ genotypes, which indicated that there were an average daily growth rate of $5.88 \pm 0.05$ and $6.27 \pm 0.09 \mathrm{~g}$ per bird per day at their 8 th weeks growth phases, respectively. Calculated heritability for 12 th week body weight of ND, $\mathrm{H}$ and $\mathrm{NN}$ were $0.16 \pm 0.39,0.50 \pm 0.05$ and $0.73 \pm 0.25$, respectively and for 16 th week body weight of $\mathrm{H}$ and ND were $0.72 \pm 0.15$ and $0.35 \pm 0.15$, respectively. Naked neck is genetically superior to non-descript Desi and Hilly in terms of productive and reproductive parameters.
\end{abstract}

Key words: Native chicken, Genotype, Performances, Heritability

\section{INTRODUCTION}

Poultry is one of the fastest growing segments of the agricultural sector in Bangladesh. It is estimated that there are about 21.81 million fowls and ducks in commercial production system and 166.59 million in subsistence production system in the total population of 188.40 million fowls and ducks in Bangladesh (Year Book of Agricultural Statistics of Bangladesh 2005). Barua and Howlider (1991) stated that naked neck chickens are better performer compared to their normal counterpart of full-feathered local chicken of Bangladesh. Under intensive rearing system, indigenous hens laid 100 110 eggs from starting to ten months of laying (Faruque and Salah Uddin 2009). By proper selection programme egg production of desi hen could be increased up to 135 eggs per year (Khan 1983). Productivity of indigenous chicken breeds may be doubled with improved diets and management conditions (Chowdhury et al. 2006). The indigenous chickens have not attained their full production potential due to exposure to risks that influence against their survival and productivity under extensive management conditions.

\footnotetext{
*Corresponding author: <siraj_blri@yahoo.com>.

${ }^{1}$ Office of Deputy Commissioner, Khagrachari, Hill District.
} 
So, Bangladesh Livestock Research Institute (BLRI) is conserving three types of native chicken, namely ND, H and NN in ex situ system. However, the research works under intensive management system on the productive parameters like body weight, egg production, egg weight and reproductive parameters like age at sexual maturity, fertility and hatchability of indigenous chickens are scanty. Therefore, the purpose of this study was to compare and evaluate the productive and reproductive performance, as well as heritability of body weight of indigenous chickens under intensive management system.

\section{MATERIALS AND METHODS}

The study was conducted at the Research Farm under Poultry Production Research Division (PPRD), Bangladesh Livestock Research Institute (BLRI), Savar, Dhaka, Bangladesh. The population under study arose from the insemination of 173 hens (ND = $110, \mathrm{H}=34, \mathrm{NN}=29$ ) with semen from cocks $(\mathrm{ND}=23, \mathrm{H}=12, \mathrm{~N}=5$ ). Insemination was done twice a week and semen of each cock was introduced to some hens. Chicks were obtained from three hatches, one or two weeks apart from January to March, 2010. Pedigree chicks were leg-banded at a-day-old. After 14 days leg-band was pulled out from leg and applied to wings. Birds were vaccinated against diseases according to the vaccination schedule. Body weights were recorded at day of hatching (Day-0) and at 8 , 12 and 16th weeks of age. Birds were weighed individually on an electronic balance, within $0.1 \mathrm{~g}$ precision. Some dams either did not lay or had no chicks at hatching and records from chicks that lost their wing bands were not included. Only data on birds having proper identified number (Pedigree and performance) were used to estimate heritability for the considered traits. After data editing, a total of 991 chicks of 32 sires and 164 dams were available for heritability estimation.

Statistical analysis: Data used in this study varied from class to class and sub-class to sub-class. Hence a non-orthogonal factorial experiment was done. Data were analyzed by $3 \times 3$ ( 3 genotypes; 3 hatches) factorial arrangement using univariate GLM procedure of SPSS 10.0 for Windows (SPSS Inc.1998) computer programme in a CRD. Correlation and regression analyses were done according to Snedecor and Cochran (1989). The differences in means were tested using Least Significant Difference (LSD) method. Variance and covariance components of the body weight traits were estimated using Residual Maximum Likelihood (REML) approach by VCE4 computer program (Groeneveld 1998). The animal model for 12 and 16 week-body-weight included the fixed effects of hatch number and sex of the chicken and birds itself as a random effect. The analysis was done in a single trait animal model. 


\section{RESULTS AND DISCUSSION}

Fertility percentage: The fertility percentage ranged from 84.95 to 97.57 in different genotypes. The highest fertility was observed in first hatch of $\mathrm{H}(97.57 \%)$ genotype as compared to remaining two genotypes (Table 1). Islam et al. (1981) reported that the fertility of upgraded indigenous chicken was $83 \%$, which was lower than the present study. Khatun et al. (2005) reported that the fertility was $94.86,88.40$ and $88.09 \%$, respectively in $\mathrm{ND}, \mathrm{H}$ and $\mathrm{NN}$ genotypes, which was more or less similar to the present findings. Uddin et al. (1995) and Islam et al. (1981) observed higher fertility (80.79\%) of Bangladeshi local chicken when compared to exotic breeds. Fertility is influenced by genetic, physiological, social and environmental factors, male-female ratio, egg production rate, nutritional status, preferential mating, lighting, sperm quality and age of hen. Kirk et al. (1980) observed that fertility declined approximately $11 \%$ from 34 to 60 weeks of hen age.

Table 1. Fertility and hatchability of native chicken eggs.

\begin{tabular}{llcccccc}
\hline Genotypes & Hatch & $\begin{array}{c}\text { No. of } \\
\text { eggs set }\end{array}$ & $\begin{array}{c}\text { Infertile } \\
\text { eggs (No.) }\end{array}$ & $\begin{array}{c}\text { Fertile } \\
\text { eggs (No.) }\end{array}$ & $\begin{array}{c}\text { Dead in } \\
\text { germ (No.) }\end{array}$ & $\begin{array}{c}\text { Fertility } \\
(\%)\end{array}$ & $\begin{array}{c}\text { Hatchability on } \\
\text { fertile eggs (\%) }\end{array}$ \\
\hline H & First & 165 & 8 & 157 & 4 & 97.57 & 79.61 \\
& Second & 110 & 10 & 100 & - & 90.91 & 82.00 \\
& Third & 318 & 34 & 257 & 27 & 89.30 & 77.82 \\
NN & First & 140 & 13 & 127 & 6 & 95.00 & 60.62 \\
& Second & 145 & 19 & 128 & 2 & 89.65 & 65.07 \\
& Third & 226 & 34 & 183 & 9 & 84.95 & 68.85 \\
ND & Third & 803 & 45 & 698 & 60 & 94.39 & 86.38 \\
\hline
\end{tabular}

Hatchability percentage: The highest hatchability was found in third hatch of ND $(86.38 \%)$ and the lowest hatchability was found in all hatches of NN genotype (Table 1). Khatun et al. (2005) showed that the hatchability on fertile eggs ranged from 78.33 to $90.79 \%$ in different genotypes with the overall percentage of 85.99 , which was much higher than the present findings. This result may be attributed by fluctuated humidity of incubator machine as it was maintained manually. Hatchability of fertile eggs is influenced by genetic environmental factors like storage temperature and humidity, care of egg, quality of eggs, age and nutrition of layers and season etc. (Olsen and Hyne 1984).

Chick-egg ratio: Egg weights prior to setting and subsequent chick weights were determined from three types of native chicken genotype namely ND, H and NN. Egg weight means were 43.50, 43.24 and $4549 \mathrm{~g}$, respectively for ND, $\mathrm{H}$ and $\mathrm{NN}$ genotypes. Chick weights were 29.12, 29.42 and $31.08 \mathrm{~g}$, respectively for ND, H and NN genotypes. The data on chick-egg ratio have shown that newly hatched chicks in the NN genotype 
had higher percentage (68.40) than chicks in the ND (67.02) and $\mathrm{H}$ (68.13) (Table 2) as chick weight was influenced $(\mathrm{p}<0.001)$ by egg weight.

Table 2. Least squares means with standard deviation for egg weight, chick weight and chickegg weight ratio at hatch of native chickens.

\begin{tabular}{llll}
\hline Genotype & Egg weight $(\mathrm{g})$ & Chick weight $(\mathrm{g})$ & Chick-egg weight ratio \\
\hline $\mathrm{ND}$ & $43.50^{\mathrm{b}} \pm 3.86$ & $29.12^{\mathrm{b}} \pm 3.20$ & $67.02^{\mathrm{b}} \pm 5.26$ \\
$\mathrm{H}$ & $43.24^{\mathrm{b}} \pm 4.34$ & $29.42^{\mathrm{b}} \pm 3.27$ & $68.13^{\mathrm{b}} \pm 4.92$ \\
$\mathrm{NN}$ & $45.49^{\mathrm{a}} \pm 4.25$ & $31.08^{\mathrm{a}} \pm 3.47$ & $68.40^{\mathrm{a}} \pm 5.65$ \\
Level of sig. & $* * *$ & $* * *$ & $* * *$ \\
\hline
\end{tabular}

${ }^{\mathrm{ab}}$ Mean \pm Sd within a column with no common superscripts differ significantly $(\mathrm{p}<0.001)$.

$* * *=$ Highly significant $(\mathrm{p}<0.001), \mathrm{Sd}=$ Standard deviation.

Body weight and body weight gain: Body weights, body weight gain, feed consumption and feed conversion ratio from a-day-old to 8th weeks of age are shown in Table 3. The average initial body weight of a-day-old chicks of ND, H and NN was $29.14 \pm 0.13$, $27.46 \pm 0.17$ and $29.46 \pm 0.20 \mathrm{~g}$, respectively and the difference was significant $(\mathrm{p}<0.001)$. While the body weight of chicks at 8 th weeks did not differ significantly $(\mathrm{p}>0.05)$ for $\mathrm{ND}, \mathrm{H}$ and $\mathrm{NN}$ genotypes.

Table 3. Effect of genotype on growth performance of native chicken under intensive rearing system ( 0 - 8 weeks).

\begin{tabular}{|c|c|c|c|c|}
\hline \multirow[b]{2}{*}{ Parameters } & \multicolumn{3}{|c|}{ Genotype } & \multirow{2}{*}{$\begin{array}{c}\text { Level of } \\
\text { significance }\end{array}$} \\
\hline & $\begin{array}{c}\text { ND } \\
(\text { Mean } \pm \text { SE) }\end{array}$ & $\begin{array}{c}\mathrm{H} \\
(\text { Mean } \pm \text { SE) }\end{array}$ & $\begin{array}{c}\text { NN } \\
(\text { Mean } \pm \text { SE) }\end{array}$ & \\
\hline Mean day-old weight (g/bird) & $29.14 \pm 0.13$ & $27.46 \pm 0.17$ & $29.46 \pm 0.20$ & $* * *$ \\
\hline $\begin{array}{l}\text { Mean final weight at } 8 \text { th weeks } \\
\text { of age ( } g / \text { bird) }\end{array}$ & $358.52 \pm 3.35$ & $373.45 \pm 4.29$ & $381.03 \pm 5.11$ & NS \\
\hline Mean body weight gain (g/bird) & $329.38 \pm 3.32$ & $345.98 \pm 4.26$ & $351.56 \pm 5.08$ & NS \\
\hline Mean daily gain (g/bird) & $5.88 \pm 0.05$ & $6.17 \pm 0.07$ & $6.27 \pm 0.09$ & NS \\
\hline Mean total feed intake (g/bird) & $1180.80 \pm 49.44$ & $1195.02 \pm 50.24$ & $1174.64 \pm 48.42$ & NS \\
\hline Mean daily feed intake (g/bird) & $20.71 \pm 0.88$ & $20.95 \pm 0.88$ & $20.60 \pm 0.88$ & NS \\
\hline FCR (feed: gain) & $3.58 \pm 0.06$ & $3.45 \pm 0.06$ & $3.34 \pm 0.06$ & NS \\
\hline
\end{tabular}

NS $=$ Non significant, $* * *=$ Highly significant $(\mathrm{p}<0.001), \mathrm{SE}=$ Standard error

Khandoker (1993) observed that body weight of native birds at hatching time and at 8th weeks of age were 25.7 and $186.5 \mathrm{~g}$, respectively. Haque (1990) found that the body weight of native birds at hatching time and at 8th weeks were 22.9 and $182.5 \mathrm{~g}$, respectively. Their observations are much lower than the present findings but the findings of Faruque et al. (2007) is much higher than the present observation who found the body weight at hatch and at 8th weeks of age for ND, $\mathrm{H}$ and NN genotypes were 31.2, 30.5, $31.7 \mathrm{~g}$ and $481.9,449.0$ and $476.0 \mathrm{~g}$, respectively. 
Feed consumption and feed conversion ratio: Feed consumption from a-day-old to 8th weeks was non-significant $(\mathrm{p}>0.05)$. The lowest and highest daily feed intake were recorded by NN (20.60 g) and $\mathrm{H}(20.95 \mathrm{~g})$. There was a non-significant ( $\mathrm{p}>0.05)$ variation in FCR among the native chicken genotypes. Growth rate affects feed conversion. The mean total feed intake for the three native chicken genotypes from day-old to $8^{\text {th }}$ weeks of their growth were $1180.80 \pm 49.44,1195.02 \pm 50.24$ and1174.64 \pm 48.42 g, respec-tively for ND, H and NN genotypes. There was non-significant $(\mathrm{p}>0.05)$ difference in total feed consumption among three tested genotypes. Khandoker (1993) found that the FCR of indigenous chicken at 8th week of age was 6.36 .

The relationship between daily gain and periods of time (weeks) was multiple (Fig. $1 ; \mathrm{y}=-0.0472 \mathrm{x}^{2}+1.2548 \mathrm{x}+0.9853 ; \mathrm{R}^{2}=0.6773$ ) but this relationship was linear up to 11 th weeks of age $\left(y=0.4937 x+2.7968 ; R^{2}=0.6031\right)$. These relationships indicated the growth rate of native chicken peaks at 11 th weeks of age and then declines.

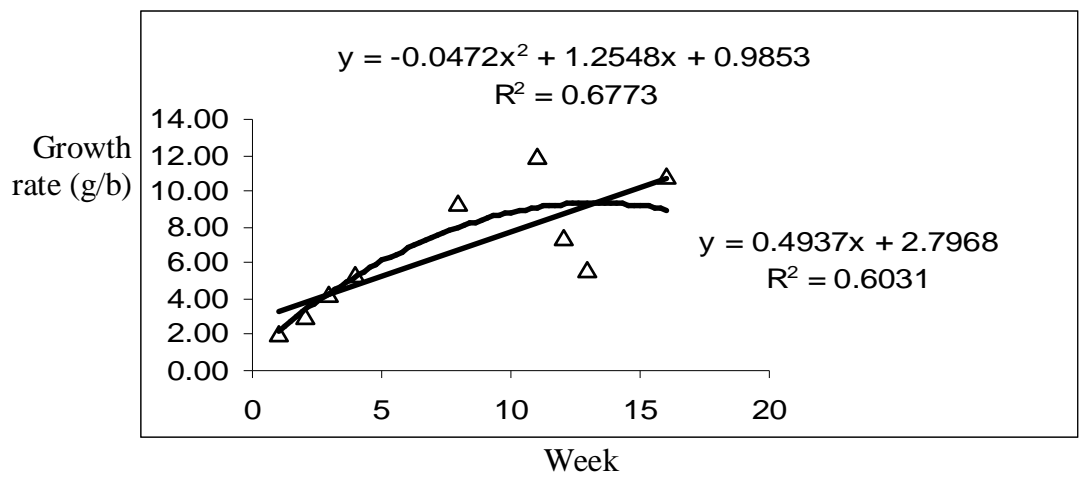

Fig. 1. Patterns of growth of native chicken over the time.

Age at sexual maturity, egg weight and hen weight at maturity: The age at sexual maturity (ASM), egg weight at sexual maturity and hen weight at sexual maturity of ND, $\mathrm{H}$ and NN chickens are shown in Table 4. The age at which native chicken birds start laying eggs ranges from 151.8 to 159.1 days. The age at sexual maturity was not significantly $(p>0.05)$ affected by genotype, hatch and genotype $\times$ hatch interaction. The birds of Hilly genotype start laying eggs at higher age as compared to naked neck genotype. The age at first egg or age at sexual maturity was comparable with same genotypes of native chicken as reported by Faruque et al. (2007). The age at sexual maturity of NN genotype (151 days) was 5 days earlier than that of $\mathrm{H}$ (156 days) in their first hatch and age at sexual maturity is not consistent with the observations of Barua (1992), Huque et al. (1990) and Sazzad (1986). They reported that NN and ND came to sexual maturity at 234 and 175 days, respectively. Hen weight at sexual maturity was 
significantly affected $(\mathrm{p}<0.05)$ by genotype but not affected $(\mathrm{p}>0.05)$ by hatch or genotype $\times$ hatch interaction. The heavier body weights at sexual maturity were found in $\mathrm{H}(1228.6 \pm 154.1 \mathrm{~g})$ in first hatch or $\mathrm{H}(1246.2 \pm 118.7 \mathrm{~g})$ in 2 nd hatch and the lowest weight in NN genotype in their first hatch $(1154.8 \pm 95.2 \mathrm{~g})$ and in 2nd hatch (1217.6 \pm $145.3 \mathrm{~g}$ ). These findings are in agreement with the findings of Faruque et al. (2007) who found the heavier body weight at sexual maturity in $\mathrm{H}(1461.2 \pm 251.0 \mathrm{~g})$ and the lowest weight in $\mathrm{NN}(1310.5 \pm 136.0 \mathrm{~g})$. Egg weight at sexual maturity was significantly affected $(\mathrm{p}<0.001)$ by genotype but not affected by hatch or genotype $\times$ hatch interaction. Egg weight at sexual maturity ranges from 25.8 to $27.1 \mathrm{~g}$. Faruque et al. (2007) found that egg weight at sexual maturity in $\mathrm{H}(28.4 \mathrm{~g})$ and in NN (29.1 g) which is a little bit higher than the present findings.

Table 4. Age at sexual maturity (d), hen weight at maturity (g) and egg weight at maturity (g).

\begin{tabular}{|c|c|c|c|c|c|c|}
\hline \multirow{3}{*}{ Trait } & \multirow{3}{*}{ Hatch } & \multicolumn{2}{|c|}{ Genotype } & \multirow{3}{*}{$\begin{array}{c}\text { Genotype } \\
\text { (G) }\end{array}$} & \multirow{3}{*}{$\begin{array}{c}\text { Hatch } \\
(\mathrm{H})\end{array}$} & \multirow{3}{*}{$\mathrm{G} \times \mathrm{H}$} \\
\hline & & $\mathrm{H}$ & $\mathrm{NN}$ & & & \\
\hline & & Mean $\pm \mathrm{Sd}$ & Mean \pm Sd & & & \\
\hline \multirow[t]{4}{*}{ Age at sexual maturity (d) } & $1 \mathrm{st}$ & $156.2 \pm 19.5$ & $151.8 \pm 9.2$ & NS & NS & NS \\
\hline & & $(48)$ & $(17)$ & & & \\
\hline & 2 nd & $159.1 \pm 7.0$ & $156.1 \pm 8.1$ & & & \\
\hline & & (44) & (29) & & & \\
\hline \multirow[t]{4}{*}{ Hen weight at maturity $(\mathrm{g})$} & $1 \mathrm{st}$ & $1228.6 \pm 154.1$ & $1154.8 \pm 95.2$ & $*$ & NS & NS \\
\hline & & $(48)$ & (17) & & & \\
\hline & 2nd & $1246.2 \pm 118.7$ & $1217.6 \pm 145.3$ & & & \\
\hline & & (44) & (29) & & & \\
\hline \multirow[t]{4}{*}{ Egg weight at maturity (g) } & $1 \mathrm{st}$ & $26.7 \pm 1.2$ & $26.0 \pm 1.6$ & $* * *$ & NS & NS \\
\hline & & (48) & (17) & & & \\
\hline & 2 nd & $27.11 \pm 1.9$ & $25.8 \pm 1.3$ & & & \\
\hline & & (44) & (29) & & & \\
\hline
\end{tabular}

NS = Non significant, $*=$ Significant at $5 \%$ level $(\mathrm{p}<0.05), * * *=$ Highly significant $(\mathrm{p}<0.001)$, $\mathrm{Sd}=$ Standard deviation.

Heritability for body weight trait: Calculated heritability for 12 th week body weight of $\mathrm{ND}, \mathrm{H}$ and $\mathrm{NN}$ were $0.16 \pm 0.39,0.50 \pm 0.05$ and $0.73 \pm 0.25$, respectively and for 16th week-body-weight of $\mathrm{H}$ and ND were $0.72 \pm 0.15$ and $0.35 \pm 0.15$, respectively. In case of $\mathrm{H}(72.0 \%)$ and of $\mathrm{NN}(35.0 \%)$ variation of 16 th week -body-weight was due to heredity and rest is controlled by environment. Differences in heritability estimates could be attributed to method of estimation, genotype, environmental effects and sampling error due to small data set or sample size. 
Table 5. Heritability estimates for body weight.

\begin{tabular}{lllll}
\hline Genotype & \multicolumn{1}{c}{ Parameter } & Mean & \multicolumn{1}{c}{$\mathrm{Sd}$} & \multicolumn{1}{c}{$\mathrm{h}^{2} \pm \mathrm{SE}$} \\
\hline $\mathrm{ND}$ & Body weight at 12 weeks $(\mathrm{g})$ & 623.83 & 61.19 & $0.16 \pm 0.39$ \\
& Body weight at 16 weeks (g) & - & - & - \\
$\mathrm{H}$ & Body weight at 12 weeks (g) & 629.54 & 145.46 & $0.50 \pm 0.05$ \\
& Body weight at 16 weeks (g) & 1053.85 & 204.99 & $0.72 \pm 0.15$ \\
NN & Body weight at 12 weeks (g) & 587.98 & 137.84 & $0.73 \pm 0.25$ \\
& Body weight at 16 weeks (g) & 1067.06 & 199.88 & $0.35 \pm 0.15$ \\
\hline
\end{tabular}

Mortality: There were 603, 405 and 285 chick records in ND, H and NN genotypes, respectively. NN genotype $(4.21 \%)$ had significantly $\left(\chi^{2}=8.27 ; \mathrm{p}<0.01\right)$ higher chick mortality than ND (1.65\%) and $\mathrm{H}(1.23 \%)$ at brooding period (0 - 4 weeks, Table 6$)$. There were 203 and 150 chick records of $\mathrm{H}$ and NN, respectively at growing period (5 13 weeks). Surprisingly, there was no significant $\left(\chi^{2}=0.765 ; \mathrm{p}>0.05\right)$ difference between $\mathrm{H}$ and $\mathrm{NN}$ genotype on chick mortality, which was 6.89 and $4.66 \%$, respectively (Table 7). There were 202, 164 and 927 chick records on 1, 2 and 3rd hatches, respectively. Chick mortality did not affected $\left(\chi^{2}=3.416 ; p>0.05\right)$ by hatch (Table 8$)$.

Table 6. Effect of genotype on chick mortality (\%) at brooding period ( 0 - 4 weeks).

\begin{tabular}{llllll}
\hline Genotype & $\mathrm{ND}$ & $\mathrm{H}$ & $\mathrm{NN}$ & $\chi^{2}(\mathrm{df}=2)$ & $\mathrm{p}$-value \\
\hline Mortality $(\%)$ & 1.65 & 1.23 & 4.21 & 8.27 & $\mathrm{p}<0.01$ \\
\hline
\end{tabular}

Table 7. Effect of genotype on chick mortality (\%) at growing period (5 - 13 weeks).

\begin{tabular}{lllll}
\hline Genotype & $\mathrm{H}$ & $\mathrm{NN}$ & $\chi^{2}(\mathrm{df}=2)$ & $\mathrm{p}$-value \\
\hline Mortality $(\%)$ & 6.89 & 4.66 & 0.765 & $\mathrm{NS}$ \\
\hline
\end{tabular}

Table 8. Effect of genotype on chick mortality (\%) at brooding period (0-4 weeks).

\begin{tabular}{llllll}
\hline Genotype & ND & H & NN & $\chi^{2}(\mathrm{df}=2)$ & p-value \\
Mortality (\%) & 2.97 & 0.61 & 1.51 & 3.416 & NS \\
\hline
\end{tabular}

\section{CONCLUSION}

It may be concluded that naked neck is genetically superior to non-descript desi and hilly in terms of above reproductive parameters like age at sexual maturity and fertility and productive parameters like egg weight, chick weight and body weight. Medium to high heritability suggests that genetic selection for body weight may be effective to improve this trait. Further study for the conservation and development of native chickens to be continued which can lead to start selection or breeding programmes in native chicken genotypes. 


\section{REFERENCES}

Barua, A.1992. A study on the performances of Rhode Island Red, indigenous chicken and their crossbred chickens with or without extra feeding under the rural condition of Bangladesh. M.Sc. Thesis, Department of Poultry Science, Bangladesh Agricultural University, Mymensingh.

Barua, A. and M.A.R. Howlider. 1991. Meat yield of free range Naked Neck and full feathered Bangladeshi chcicken. Indian Journal of Animal Sciences 61: 772-775.

Bhuiyan, A.K.F. H., M.S.A. Bhuiyan and G.K. Deb. 2005. Indigenous chicken genetic resources in Bangladesh: Current status and future outlook. Animal Genetic Resources Information's Bulletin, No. 36, pp. 73-84.

Chowdhury, S.D., S. Ahmed and M.A. Hamid. 2006. Improved feeding of desi chicken reared in confinement. The Bangladesh Veterinarian 23: 29-35.

Faruque, S.2 N.R. Sarker, M.N. Islam and M.S.K. Sarker. 2007. Performance of native chicken under intensive system. Journal of the Bangladesh Agricultural University 5 (2): 283-288.

Faruque, S., and M. Salah Uddin. 2009. Study on Molecular Genetic Diversity of Native Chickens in Bangladesh: Phenotypic characterization of Native Chicken. Proceedings of the Annual Research Review Workshop, Bangladesh Livestock Research Institute, Savar, Dhaka, 15-16 June, pp. 70.

Groeneveld, E. 1998. VCE4 User's Guide and Reference Manual Version1.1. Institute of Animal Husbandry and animal Behaviour. Mariensee, Federal Agricultural Research Center, Germany.

Halima, H. 2007. Phenotypic and genetic characterization of indigenous chicken populations in Northwest Ethiopia. Ph.D Thesis, Faculty of Natural and Agricultural Sciences, Department of Animal, Wildlife and Grassland Sciences, University of the Free State, Bloemfontein, South Africa, pp. 95-96.

Haque, M.E. 1990. A study on the performance of native chicks and their mother hens with or without under village condition. Master of Science in Poultry Science, Thesis, submitted to the Department of Poultry Science, Bangladesh Agricultural University, Mymensingh.

Huque, Q.M.E., E. Haque and E. M. Rigor. 1990. Effect of chick separation on productivity of the hen and chick. Asian Australasian Journal of Animal Science 3(2): 121-123.

Islam, A.B.M.M. 1969. A comparative study on egg production, egg size, fertility, hatchability, growth rate and seasonal maturity of different upgraded indigenous chickens of East Pakistan. M.Sc. Thesis, Bangladesh Agricultural University, Mymensingh

Islam, A.B.M.M., M.M. Huque and Q.M.F. Rahim. 1981. Reproductive performance of upgraded indigenous chicken. Poultry Adviser 17: 32-37.

Kamble, K.D., D.P. Singh, D.C. Jori and R.D. Sharma. 1996. Reproductive performance of various Indian native breeds and their crosses with Dahlem Red. Proceedings of the $X X$ World's Poultry congress, New Delhi, India, 2-5 September. pp. 36.

Khandoker, M.A.M.Y. 1993. Performance of Indigenous (desi), Rhode Island Red (RIR) and Desi $\times$ RIR chickens under farm condition. Master of Science in Poultry Science, Thesis, submitted to the Department of Poultry Science, Bangladesh Agricultural University, Mymensingh.

Khan, A.G. 1983. Improvement of desi bird (part-2). Poultry Adviser 16: 67-78.

Khatun, R., M. S. Islam, S. Faruque, S.A. Azmal and M.S. Uddin. 2005. Study on the productive and reproductive performance of 3 native genotypes of chicken under intensive management. Journal of Bangladesh Agricultural. University 3(1): 99-104.

Kinney, T.R.Jr. 1969. A summary of reported estimates of heritabilities and of genetic and phenotypic correlations for traits of chickens. Handbook No. 363 Agricultural Research Service. pp. 44. 
Kirk, S., G.C. Emmans, R. McDonald and D. Arnot. 1980. Factors affecting the hatchability of eggs from broiler breeders. British Poultry Science 21: 37-53.

Lwelamira, J., G.C. Kifaro and P.S. Gwakisa. 2008. Genetic parameters for body weights, egg traits and antibody response against Nawcastle Disease Virus (NDV) vaccine among two Tanzania chicken ecotypes. Springer Link Journal Article http:॥www.springerlink.com/ content/r9u35547425m112h/

Malony, M.A., J.C. Cylilbreath, D. Robert and D. Morrison. 1963. Two way selection for body weight in chicken. Poultry Science 42: 326.

Maphosa, T., J. Kusina, N.T. Kusina S.M. Makuza and S. Sibana. 2002. Effect of housing on chick mortality in small holders area in Narira Lancashire Zimbabwe. Proceedings of the $7^{\text {th }}$ World's Poultry Science Association Asian Pacific Federation Conference, Gold Coast Australia. pp. 500-510.

Olsen, M.W. and S.K. Hyne. 1984. The effect of different holding temperatures on the hatchability of hen eggs. Poultry Science 27: 420-426.

Salah Uddin, M., T. Yeasmin and M.A.R. Howlider. 1995. Relationship between fertility and hatchability with egg weight of free-range native chicken. Bangladesh Journal of Training and Development 8(192): 99-102.

Saleque, M.A. 2001. Poultry as a tool in poverty alleviation: A especial programme for the rural poor in Bangladesh. Proceedings of the 2nd International Poultry Show and Seminar. Organized by World's Poultry Science Association, Bangladesh Branch. February 16-17, IDB Bhaban Sher-e-Bangla Nagar, Dhaka, Bangladesh, pp. 66-76.

Saleque, M.A. and S. Mustafa. 1996. Landless women and Poultry : The BRAC Model in Bangladesh in Frands Dolberg and Poul Henning Petersen (eds) Integrated Farming in Human Development. Proceedings of the Workshop, March 25-29, Tune Landboskole Denmark, pp. 38-55.

Sarker, K. 2007. A transition from subsistence to semi-commercial family poultry farming with indigenous chickens. Proceedings of the 5th International Poultry Show and Seminar. World's Poultry Science Association Bangladesh Branch. pp. 151-161.

Sazzad, M.H. 1986. Reproductive performance of deshi hens under scavenging and intensive system of rearing. Proceedings of the 1st Annual Report, Bangladesh Livestock Research Institute, Savar, Dhaka, Bangladesh.

Snedecor, G. W. and W. G. Cochran.1989. Statistical Methods, 8th edn. The Iowa State University Press, Ames, IA, USA.

SPSS (STATISTICAL PROCEDURES FOR SOCIAL SCIENCES). 1998. SPSS 10.0 for windows.

Year Book of Agricultural Statistics of Bangladesh. 2005. Bangladesh Bureau of Statistics. pp. 239. 